\section{Loyalitas Kreativitas \\ Aldi Masyarakat Kreatif}

P-ISSN 2722-2101, E-ISSN 2722-4201

Program Studi Ekonomi Manajemen Universitas Pamulang Jurnal LOKABMAS Kreatif Vol. 01, No. 01, Hal. 15-20

Email:jurnalkreatif.manajemen@gmail.com

\title{
PEMBERDAYAAN IBU PKK RW 05 KELURAHAN KUNINGAN BARAT JAKARTA SELATAN MELALUI PELATIHAN MANAJEMEN USAHA KERAJINAN (CRAFT) DECOUPAGE UNTUK MENINGKATKAN EKONOMI KELUARGA
}

\author{
Jeni Andriani, Retno Wulansari, Sri Retnaning Sampurnaningsih, Nofiar, Fitri Sabina \\ Dosen Prodi Manajemen Fakultas Ekonomi Universitas Pamulang \\ Email : dosen00436@unpam.ac.id, dosen00568@unpam.ac.id, dosen01366@unpam.ac.id, \\ dosen01737@unpam.ac.id,dosen02019@unpam.ac.id
}

\begin{abstract}
ABSTRAK
Pengabdian ini berjudul Pemberdayaan Ibu PKK RW 05 Kelurahan Kuningan Barat Jakarta Selatan Melalui Pelatihan Manajemen Usaha Kerajinan (Craft) Decoupage Untuk Meningkatkan Ekonomi Keluarga.

Tujuan dari Pengabdian kepada Masyarakat ini adalah untuk mengetahui dampak pemberdayaan ibu PKK melalui pelatihan kerajinan (craft) decoupage, untuk mengetahui kemampuan manajemen usaha ibu PKK, dan untuk mengetahui peran ibu PKK dalam meningkatkan ekonomi keluarga.

Metode yang digunakan dalam pengabdian ini adalah penyuluhan dan pelatihan manajemen usaha dalam membuat kerajinan (craft) decoupage.

Hasil dari kegiatan ini adalah memberikan dampak bahwa pemberdayaaan ibu PKK RW 05 Kelurahan Kuningan Barat Mampang Prapatan Jakarta Selatan melalui kerajinan (craft) decoupage menunjukkan adanya kreativitas dan ketrampilan sebagai potensi diri, kemampuan manajemen usaha masih belum semuanya maksimal dikarenakan pengetahuan yang dimiliki masih terbatas, dan adnya peran ibu PKK RW 05 Kelurahan Kuningan Barat Mampang Prapatan Jakarta Selatan untuk meningkatkan ekonomi keluarga untuk membuka usaha kerajinan (craft) decoupage.
\end{abstract}

Kata kunci : Pemberdayaan,Manajemen Usaha, Decoupage, Ekonomi Keluarga

\section{ABSTRAC}

This service is entitled Empowerment of Mother PKK RW 05, Kuningan Barat, South Jakarta through Training Decoupage Business Management to Improve Family Economy.

The purpose of this service is to find out the impact of empowering PKK mothers through craft training (decoupage craft), to know the business management capabilities of PKK mothers, and to find out the role of PKK mothers in improving the family economy.

The method used in this service is counseling and business management training in making decoupage crafts.

The result of this activity is that the empowerment of PKK RW 05, Kuningan Barat Mampang Prapatan, South Jakarta through the decoupage craft shows creativity and skills as self potential, business management capabilities are still not entirely maximal due to limited knowledge, and the role of the PKK RW 05 mother of Kuningan Barat Mampang Prapatan South Jakarta to improve the family economy to open a decoupage craft business. 


\section{Loyalitas Kreativitas \\ Aldi Masyarakat Kreatif}

P-ISSN 2722-2101, E-ISSN 2722-4201

Program Studi Ekonomi Manajemen Universitas Pamulang Jurnal LOKABMAS Kreatif Vol. 01, No. 01, Hal. 15-20

Email:jurnalkreatif.manajemen@gmail.com

\section{Keywords: Empowerment, Business Management, Decoupage, Family Economy}

\section{PENDAHULUAN}

Gerakan PKK (Pemberdayaan dan Kesejahteraan Keluarga) bertujuan memberdayakan keluarga untuk meningkatkan kesejahteraan menuju terwujudnya keluarga yang beriman dan bertaqwa kepada Tuhan yang Maha Esa, berakhlak mulia dan berbudi luhur, sehat sejahtera, maju dan mandiri, kesetaraan dan keadilan gender serta kesadaran hukum dan lingkungan.

Tim Penggerak PKK berperan sebagai motivator, fasilitator, perencana, pelaksana, pengendali dan penggerak. Pembinaan tehnis kepada keluarga dan masyarakat dilaksanakan dalam kerjasama dengan unsur dinas instansi pemerintah terkait.

Sasaran gerakan PKK adalah keluarga, baik di pedesaan maupun perkotaan yang perlu ditingkatkan dan dikembangkan kemampuan dan kepribadiannya, dalam bidang:

1. Mental spiritual meliputi sikap dan perilaku sebagai Insan hamba Tuhan, anggota masyarakat dan warga negara yang dinamis serta bermanfaat, berdasarkan Pancasila dan UndangUndang Dasar 1945.

2. Fisik material meliputi pangan, sandang, papan, kesehatan, kesempatan kerja yang layak serta lingkungan hidup yang sehat dan lestari melalui peningkatan pendidikan, pengetahuan dan keterampilan.

Berlandaskan analisa situasi tersebut, di mana kelurahan Kuningan Barat Mampang Prapatan termasuk salah satu wilayah yang padat pemukimannya di Jakarta Selatan dan adanya gerakan PKK yang mempunyai prinsip pemberdayaan dan partisipasi masyarakat lewat pemberdayaan keluarga, maka kegiatan Pengabdian kepada Masyarakat (PKM) dosen-dosen dan mahasiswa Prodi Manajemen Fakultas Ekonomi Universitas Pamulang ini dilakukan agar ibu PKK mahir membuat kerajinan (craft) decoupage menjadi suatu usaha kreatif sehingga bisa meningkatkan pendapatan ekonomi keluarganya.

\section{RUMUSAN MASALAH}

Adapun perumusan masalah adalah

1. Bagaimana dampak pemberdayaaan ibu PKK melalui pelatihan kerajinan (craft) decoupage?

2. Bagaimana kemampuan manajemen usaha ibu PKK ?

3. Bagaimana peran ibu PKK untuk meningkatkan ekonomi keluarga?

\section{TUJUAN PELAKSANAAN}

1. Untuk mengetahui dampak pemberdayaan ibu PKK melalui pelatihan kerajinan (craft) decoupage.

2. Untuk mengetahui kemampuan manajemen usaha ibu PKK.

3. Untuk mengetahui peran ibu PKK dalam meningkatkan ekonomi keluarga.

\section{TINJAUAN PUSTAKA}

\section{Pemberdayaan}

Pemberdayaan menurut arti secara bahasa adalah proses, cara, perbuatan membuat berdaya, yaitu kemampuan untuk melakukan sesuatu atau kemampuan bertindak yang berupa akal, ikhtiar atau upaya (Depdiknas, 2003)

2. Manajemen Usaha

Manajemen usaha adalah proses merencanakan, mengarahkan, mengorganisir, dan mengendalikan kegiatan untuk mencapai tujuan organisasi secara efektif dan efisien melalui pemanfaatan sumber daya organisasi. (Ricky W. Griffin, 2005)

Manajemen usaha meliputi manajemen keuangan, manajemen SDM, dan manajemen pemasaran.

\section{Kerajinan Decoupage}

Decoupage adalah seni kerajinan dari Perancis yang masuk ke Indonesia 
Email:jurnalkreatif.manajemen@gmail.com

sebelum tahun 2000. Decoupage adalah seni melapis barang dengan menggunakan tisu impor dengan berbagai media yaitu clutch pandan, gantungan kunci, tatakan gelas, kaleng mini, kotak perhiasan, jam kayu, talenan kayu hiasan dinding, gelas kaca, botol, kalung mutiara (teknik suspenso), stoples, piring, tas kain, dan kanvas lukis. (Hendraidjat, 2016)

\section{Ekonomi Keluarga}

Ekonomi keluarga adalah upaya manusia untuk memenuhi kebutuhankebutuhannya melalui aktivitasaktivitas yang dilakukan oleh seseorang yang bertanggung jawab atas kebutuhan dan kebahagiaan bagi kehidupannya.(https://www.scribd.co m/doc/297694243/Pengertian-

Ekonomi-Keluarga, diakses tanggal 30 Desember 2019)

\section{METODE PELAKSANAAN}

Metode yang digunakan dalam kegiatan PKM ini adalah penyuluhan manajemen usaha dan praktek pelatihan kepada 30 orang ibu-ibu PKK dengan kerajinan (craft) decoupage. Waktu Pelaksanaan tanggal 24-25 November 2019 Bertempat di Aula Mushola RW 05 Kelurahan Kuningan Barat Mampang Prapatan Jakarta Selatan.

Kegiatan PKM dibagi menjadi dua yaitu tahap persiapan dan tahap pelaksanaan.

Tahap persiapan meliputi :

a) Tahap Pertama : Informasi awal, pada tahap ini didapatkan infomasi awal dari anggota PKK Kuningan Barat Mampang Prapatan Jakarta Selatan

b) Tahap Kedua : Pemantapan konsep PKM yang berupa penyuluhan manajemen usaha disertai pembekalan kerajinan (craft) decoupage, dalam wadah komunitas ibu-ibu PKK RW 05 Kelurahan Kuningan Barat.

c) Tahap Ketiga : Pembuatan instrumen pelaksanaan kegiatan Pengabdian Kepada Masyarakat, berupa handout presentasi dan sampel praktek kerajinan (craft) decoupage.

d) Tahap Keempat : Persiapan alat dan bahan, terdiri dari:

1) Alat dan bahan presentasi

2) Alat dan bahan pembuatan praktek kerajinan (craft) decoupage.

Tahap pelaksanaan meliputi tentang materi pemberdayaan ibu-ibu PKK di mana sesi ini menitikberatkan pada pemaparan materi mengenai bagaimana menjadi ibu rumah tangga yang produktif dan bisa membantu/meningkatkan ekonomi keluarga dengan memiliki keterampilan usaha, kemudian dilakukan metode demonstrasi yang diikuti sesi diskusi dan tanya jawab, dilanjukan metode simulasi untuk menunjukan contoh kepada para peserta dalam mengerjakan/praktek membuat kerajinan (craft) decoupage dari tas/dompet anyaman.

\section{HASIL DAN PEMBAHASAN}

Hasil kegiatan ini umumnya hampir seluruh peserta sangat antusias mengikuti penyuluhan dan pelatihan sehingga mendapatkan hasil yang sangat memuaskan, karena sebelumnya belum pernah mendapatkan materi manajemen usaha dan pelatihan kerajinan (craft) decoupage. Dalam pelatihan ini peserta praktek langsung membuat sendiri kerajinan (craft) decoupage dengan media dompet (clutch) anyaman.Dampak kegiatan pemberdayaaan ibu PKK RW 05 Kelurahan Kuningan Barat Mampang Prapatan Jakarta Selatan melalui kerajinan (craft) decoupage menunjukkan adanya kreativitas dan ketrampilan sebagai potensi diri yang terus digali dan ditingkatkan kemampuannya.

Pada tahap akhir dilakukan pengujian kemampuan dengan tanya jawab dan selanjutnya dilakukan evaluasi terhadap hasil kegiatan pelatihan.

Hari pertama kegiatannya berupa penyuluhan dengan penyampaian materi pemberdayaan ibu-ibu PKK sebagai ibu rumah tangga yang produktif dan bisa membantu atau meningkatkan ekonomi keluarga dengan memiliki keterampilan 


\section{Loyalitas Kreativitas \\ Aldi Masyarakat Kreatif}

P-ISSN 2722-2101, E-ISSN 2722-4201

Pamulang

Program Studi Ekonomi Manajemen Universitas

Jurnal LOKABMAS Kreatif Vol. 01, No. 01, Hal. 15-20

Email:jurnalkreatif.manajemen@gmail.com

usaha, selanjutnya dilakukan tahap diskusi dan tanya jawab. Penyampaian materi diberikan oleh tim PKM dan dibantu oleh satu orang mahasiswa.

Dilanjukan hari kedua kegiatan berupa pelatihan, dengan pengenalan bahan dan alat kemudian dijelaskan bagaimana teknik membuat decoupage dengan media dompet (clucth) anyaman. Penyampaian materi pelatihan praktek kerajinan (craft) decoupage diberikan oleh tim PKM dan dibantu oleh dua orang mahasiswa.

\section{KESIMPULAN DAN SARAN \\ Kesimpulan}

1. Dampak kegiatan pemberdayaaan ibu PKK RW 05 Kelurahan Kuningan Barat Mampang Prapatan Jakarta Selatan melalui kerajinan (craft) decoupage menunjukkan adanya kreativitas dan ketrampilan sebagai potensi diri yang terus digali dan ditingkatkan kemampuannya.

2. Kemampuan manajemen usaha ibu PKK RW 05 Kelurahan Kuningan Barat Mampang Prapatan Jakarta Selatan masih belum semuanya maksimal dikarenakan pengetahuan yang dimiliki masih terbatas.

3. Peran ibu PKK RW 05 Kelurahan Kuningan Barat Mampang Prapatan Jakarta Selatan untuk meningkatkan ekonomi keluarga sebagai ibu rumah tangga membuka usaha kerajinan (craft) decoupage.

\section{Saran}

1. Adanya pelatihan-pelatihan keterampilan lain untuk menggali atau meningkatkan potensi/kemampuan yang sudah dimiliki ibu PKK, seperti kuliner, menjahit

2. Perlu adanya pelatihan manajemen usaha lainnya seperti pemasaran melalui E-Commerce.

3. PKK sebagai wadah anggotanya bisa untuk menampung dan memasarkan hasil-hasil produk usaha rumahan (home industry).

\section{DAFTAR PUSTAKA}

Ambar, Teguh Sulistiyani. 2004. Memahami Good Governance: Dalam Perspektif Sumber Daya Manusia, Yogyakarta : Gaya Media

Depdiknas. 2003. Kamus Besar Bahasa Indonesia, Edisi Ketiga, Jakarta: Balai Pustaka.

Griffin, Ricky W. 2005. Bisnis Inernasional : Perspektif Manajerial. Jakarta : Indeks https://www.futuready.com/artikel/lifestyle -leisure/apa-peran-ibu-pkk pembinaan kesejahteraan-keluarga, diakses tanggal 11 Oktober 2019

https://www.scribd.com/doc/297694243/Pe ngertian-Ekonomi-Keluarga, diakses tanggal 30 Desember 2019

Nurlaila dan Lilies Yulastri. 2017. Pemberdayaan Ibu PKK Kelurahan Rawamangun Dalam Pelatihan Membuat Decoupage Dari Tissue Berbasis Industri Kreatif. Jurnal Sarwahita Vol. 14 No. 02 Tjandra, Hendraidjat. 2016. Berkreasi Berbagi Teknik Decoupage Bersama Inspiration Craft. Jakarta : Gramedia Pustaka Utama

Pasaribu, V. L. D., Agrasadya, A., Shabrina, N., \& Krisnaldy, K. (2020). MENJADI ENTERPRENEUR MUDA

YANG MEMILIKI JIWA LEADERSHIP UNTUK MENGHADAPI MASA DEPAN. Abdi Laksana, 1(1)

Pasaribu, V. L. D., Elburdah, R. P., Sudarso, E., \& Fauziah, G. (2020). PENGGUNAAN MANAJEMEN WAKTU TERHADAP PENINGKATAN PRESTASI BELAJAR DI SMP ARAISIYAH. Jurnal ABDIMAS, 1(1)

Pasaribu, V. L. D., Susanti, F., \& Hartuti, E. T. K. (2019). MEMOTIVASI SISWA DAN SISWI SMK LETRIS INDONESIA DI DALAM MENENTUKAN PILIHAN 
Loyalitas Kreativitas

Aldi Masyarakat Kreatif
P-ISSN 2722-2101, E-ISSN 2722-4201

Program Studi Ekonomi Manajemen Universitas Pamulang

Jurnal LOKABMAS Kreatif Vol. 01, No. 01, Hal. 15-20

Email:jurnalkreatif.manajemen@gmail.com

UNTUK MELANJUTKAN

PENDIDIKAN ATAU BEKERJA

SETELAH LULUS SEKOLAH. Jurnal

Pengabdian Dharma Laksana, 1(2), 161-

172.

\section{DOKUMENTASI FOTO KEGIATAN}
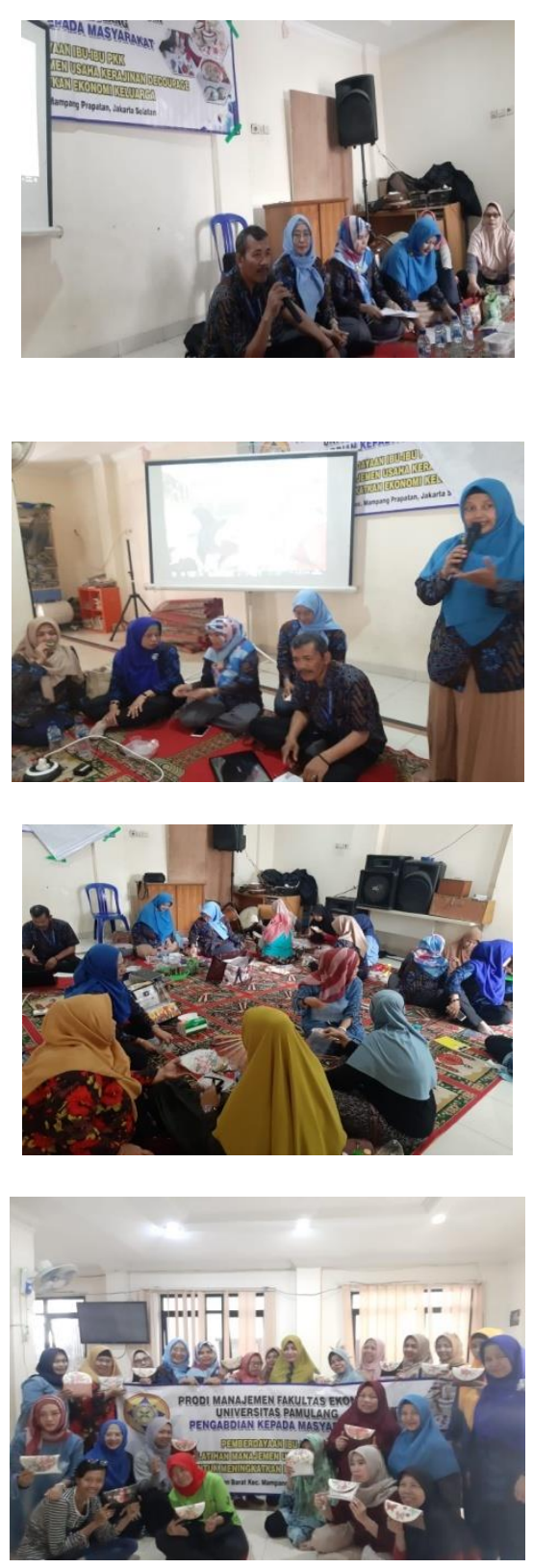